J Vis (2011) 14:399

DOI 10.1007/s12650-011-0111-0

\title{
ERRATUM
}

Seiichiro Morizawa - Koji Shimoyama • Shigeru Obayashi · Kenichi Funamoto •

Toshiyuki Hayase

\section{Erratum to: Implementation of visual data mining for unsteady blood flow field in an aortic aneurysm}

Published online: 10 November 2011

(C) The Author(s) 2011. This article is published with open access at Springerlink.com

\section{Erratum to: J Vis}

$$
\text { DOI 10.1007/s12650-011-0101-2 }
$$

The category of 'Implementation of visual data mining for unsteady blood flow field in an aortic aneurysm' paper is 'Regular Paper.'

The paper was published as 'Review Paper' by mistake.

Editor-in-Chief Prof. M. Kawahashi

Open Access This article is distributed under the terms of the Creative Commons Attribution Noncommercial License which permits any noncommercial use, distribution, and reproduction in any medium, provided the original author(s) and source are credited.

The online version of the original article can be found under doi:10.1007/s12650-011-0101-2.

S. Morizawa $(\bowtie) \cdot$ K. Shimoyama $\cdot$ S. Obayashi $\cdot$ K. Funamoto $\cdot$ T. Hayase

Institute of Fluid Science, Tohoku University, 2-1-1 Katahira, Aoba-ku, Sendai 980-8577, Japan

E-mail: morizawa@edge.ifs.tohoku.ac.jp

Tel.: +81-22-2174438

Fax: $+81-22-2174438$ 